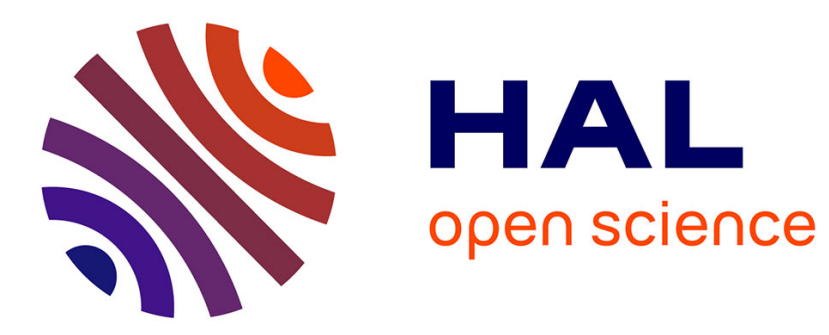

\title{
Teaching Musical Fiction
}

Marcin Stawiarski

\section{To cite this version:}

Marcin Stawiarski. Teaching Musical Fiction. Journal of Aesthetic Education, 2008, 42 (4), pp.78-88. 10.1353/jae.0.0027 . hal-02266699

\section{HAL Id: hal-02266699 \\ https://hal.science/hal-02266699}

Submitted on 19 Aug 2019

HAL is a multi-disciplinary open access archive for the deposit and dissemination of scientific research documents, whether they are published or not. The documents may come from teaching and research institutions in France or abroad, or from public or private research centers.
L'archive ouverte pluridisciplinaire HAL, est destinée au dépôt et à la diffusion de documents scientifiques de niveau recherche, publiés ou non, émanant des établissements d'enseignement et de recherche français ou étrangers, des laboratoires publics ou privés. 


\title{
TEACHING MUSICAL FICTION
}

\author{
Marcin STAWIARSKI \\ University of Poitiers \\ FORELL E.A.3816
}

Personal working paper version: May 2008

\begin{abstract}
Given the increasing interest in musico-literary studies and extended bibliographies of intermedial texts, it is necessary to reconsider the use of intersemiotic teaching materials. Musical fiction calls for a specific approach and requires specialized knowledge. But using musically inspired novels and short stories in the classroom along with musical materials proves an enriching experience. In my opinion, the importance of the role played by intermediality lies in the fact that it allows us to raise questions about textuality and literariness through contrastive analysis. It also seems to me that it is essential to broaden interartistic teaching materials by introducing musical auxiliary materials in literature classes on the same level as picture or film analysis.
\end{abstract}

\section{Introduction}

Given the increasing interest in musico-literary studies, I wish to examine some ways in which music can be used for pedagogical purposes in teaching literature. It has been widely recognized that music and poetry sprang from a common origin as chant or incantation [1]. Throughout the ages, the sister arts sometimes went hand in hand, sometimes parted company, but since the end of the 19th century musical aspects have been massively used in literature, either as a subject matter or as a wellhead of structures. The number of musically inspired 20th-century novels bears evidence to this strengthening of musico-literary relationships [2]. Contemporary interactive, interdisciplinary and multi-medial works of art or artistic events also testify to a close sisterhood between the arts. This phenomenon has come to be called intermediality, defined as using more than one artistic medium in the creation of a work of art. But then, examining musical aspects in literature demands specific knowledge of the musical field itself, thus raising questions about the limits and the difficulties of using musico-literary materials in class. Suppose the student were not knowledgeable at all about music. What can then be the input the teacher can offer the student without necessarily inundating the latter with too much information? Is it possible to avoid generalizations in drawing comparisons or distinctions between music and literature? And, is it relevant to deal with music in teaching fiction?

I wish to suggest that there are pragmatic elements of music which may be used in teaching music-related texts without previous skills in the musical field. In this respect, music may serve as an enriching and fascinating teaching tool. The point I would like to make is that quite often music leads the text to raise questions about literariness itself, so that it becomes possible not only to discuss musico-literary interrelations, but to tackle the specificity of literature through the prism of intermediality.

This paper will deal with two kinds of musico-literary phenomena appearing in fiction. On the one hand, I wish to examine the implications of the historical and cultural background in musicalized texts as an inherent aspect of many novels. On the other hand, I wish to broach 
the question of the musicalization of fiction, that is to say the transposition or imitation of musical forms in literature.

\section{1) Literature speaking about music}

\section{The need of a context}

In dealing with musical contexts of literary texts, the teacher may bring the student's attention to bear on the variety of ways a text may be related to music. A typology of different musicoliterary interrelations has been established by such critics as Calvin S. Brown [3] or Steven P. Scher [4]. In Scher, one may find a useful chart, dividing the musico-literary studies into two categories: literary presence within the musical field (explored by musicology) and musical presence within the literary field (explored by literary studies). The latter may be subdivided into word music, musical structures and verbal music. This typology has been furthered by Werner Wolf in his critical work on the musicalization of fiction. Yet too detailed a categorization may seem difficult to put into practice in class. Its principle drawback lies in the difficulty to sever one musical phenomenon in literature from the other. In numerous cases it seems impossible to drive an unequivocal wedge between a) prosodic phenomena, appertaining to word music or musicality, b) exclusively thematic or topical elements and c) specifically structural transpositions. Such an accurate classification would thus be preferably used with more advanced students.

The thematic or topical relationship I want to focus on in this part is by far the easiest to get across to students, since it does not require musical skills. This approach is roughly tantamount to Scher's verbal music or Wolf's thematization [5], and it appears in texts dealing with music explicitly.

Many texts resort to an extramusical (or paramusical) rather than a purely musical content. In other words, it is the critical or mythical context surrounding a given musical work that is often used in fiction. In reading Rose Tremain's novel, Music and Silence, it is necessary to account for the historical context of the musical elements in the text. The setting of the King's table concerts - played by a group of musicians hidden in a cellar so that the sound might be transmitted from below - clearly draws on the baroque custom of Tafelmusik. The context may thus be explained to students with the aid of non fictional historical or musicological texts [6]. Such texts may spur discussion about music used as a background to feasts and banquets, and it seems useful to make students listen to relevant musical excerpts [7].

Accordingly, contemporary listening habits may be worth debating. What has come to be called Muzak - music one cannot help listening to in elevators or waiting on the phone, or background and ambient music in a restaurant - may constitute a fruitful ground for an interesting discussion on the role music plays in our everyday life.

In relation to Tremain's novel, some phenomenological aspects of music may also be tackled. Indeed, contrary to seeing, hearing cannot be avoided, since "our ears have no eyelids," as the contemporary French writer, Pascal Quignard, puts it [8]. Tremain's novel toys with this specific sound property. In addition to this phenomenological impossibility to avoid hearing, one may point to the instability of sound and its incapacity to be perceived as part of an objectified, realistic universe. Hence, the role of music in realistic fiction, where it can sometimes participate in the referential illusion or signify the milieu, is completely different from the role of music in gothic fiction. The latter resorts precisely to the anti-realistic, uncanny instability of sound, which appears clearly enough in Ann Radcliffe's The Mysteries 
of Udolpho. Here music exerts a crucial function in the construction of the plot. The mystery builds up thanks to the intermittent and unstable nature of sounds which exacerbate the uncanny. Hence, a meditation on sound perception may constitute a helpful ancillary subject matter to historical contextualization of texts dealing with music.

I wish to point to yet another example of historical or cultural contextualization of a musicoliterary work. Gabriel Josipovici's Goldberg: Variations stages a character, Goldberg, arriving at a manor where he is to read to his employer, Westfield. The latter suffers from insomnia, and decides to hire a writer to read for him during the night from a room adjacent to his own, so that it may alleviate his suffering or make him finally fall asleep. In the first chapter, it turns out that Westfield had tried employing a musician earlier on, but the musical remedy fell through. That is why, as a writer, Goldberg is to compose his own texts and read them out for Westfield. The novel sets up an intersemiotic dynamics, akin to rivalry between the arts. The musical context relates to J. S. Bach's Goldberg Variations, and it would be instructive to make students listen to the composition, at least the introductory theme: the Aria. In spite of the difficulty that the analysis of the score may present, it may be spoken of on quite a general level, through its extramusical context. In fact, Bach's first biographer, Johann Nikolaus Forkel reports that the composition was commissioned by Count Hermann Keyserling who suffered from insomnia. Goldberg was to perform the variations for Keyserling in an adjacent room. The legend is thus an interesting prerequisite for understanding Josipovici's novel.

\section{Representing the listener}

Speaking of multifarious musical contexts, one may also tackle the historical aspects of reception by examining texts that depict the topos of the concert. The opera scene is frequently used in the 19th-century novel as a theatrical mirror of the milieu. In Balzac's novels, to take an instance, opera emerges as a mirror and a means of discovery of the Parisian society [9]. The heuristic value of the concert representation appears in many a book, only to mention Villiers de l'Isle-Adam's short story, "Unknown Woman," or Willa Cather's novel, The Song of the Lark.

Besides, the intimacy of the private reception (chamber music, as in Proust's Remembrance of Things Past) may be contrasted with public performances. Contrastive analysis reveals rich social and historical implications. Romantic reception, as in Kate Chopin's The Awakening, may be paralleled with Virginia Woolf's short story, "The String Quartet," both within the dynamics of contrast between public and private spheres, and within the scope of an evolving musical sensibility. The heroine of The Awakening, Edna, does not really listen to music for sounds, but for pictures or images:

Edna was what she herself called very fond of music. Musical strains, well rendered, had a way of evoking pictures in her mind. She sometimes liked to sit in the room of mornings when Madame Ratignolle played or practiced. One piece which that lady played Edna had entitled "Solitude." [...] When she heard it there came before her imagination the figure of a man standing beside a desolate rock on the seashore. He was naked. His attitude was one of hopeless resignation as he looked toward a distant bird winging its flight away from him. (Chopin, 44)

On listening to one of Chopin's Impromptus, the heroine visualizes a watery landscape:

Edna did not know when the Impromptu began or ended. She sat in the sofa corner reading Robert's letter by the fading light. [...] The shadows deepened in the little room. The music grew strange and fantasticturbulent, insistent, plaintive and soft with entreaty. The shadows grew deeper. The music filled the room. It floated out upon the night, over the housetops, the crescent of the river, losing itself in the silence of the upper air. (Chopin, 106)

The association of water and music hints at the notion of programme music which presupposes both a specific stance towards musical signification and a particular response to music. It tackles the problem of reception on the whole, with all possible stereotypical 
implications it may engender. The pictorialization of music in The Awakening foreshadows the very end of the novel, but it also reminds one of the long-debated dispute between the proponents of pure music and the advocates of musical expressivity. This topic may be an interesting vantage point from which the subject of music in literature may be tackled in class.

One may also broach the question of clichés of musical reception. Just as in The Awakening, the protagonist of Virginia Woolf's short story, "The String Quartet", sees pictures when listening to music. We are given a direct account of the character's thoughts through the technique of the stream of consciousness. It is noteworthy that in Woolf's story the pictures provoked by music are quite incongruous. Indeed, if the very beginning of the concert refers to fours musicians, the remainder of the concert involves trumpets or clarions. Moreover, through their watery quality the described images remind one of Schubert's Trout, a quintet rather than a quartet:

Flourish, spring, burgeon, burst! The pear tree on the top of the mountain. Fountains jet; drops descend. But the waters of the Rhone flow swift and deep, race under the arches, and sweep the trailing water leaves, washing shadows over the silver fish, the spotted fish rushed down by the swift waters, [...], conglomeration of fish all in a pool; leaping, splashing, scraping sharp fins; and such a boil of current that the yellow pebbles are churned round and round, round and round [...]. (Woolf, 22)

Through the magnified painterly technique - one might talk about hypotyposis or even ekphrasis, thus a pictorial depiction rather than a sonorous one -, the text seems to highlight the stereotypical nature of musical reception. The dialogues appearing in between the snatches of the stream of consciousness undermine the habits of the concert. In the upshot, the protagonist turns away from the sophisticated world of concert-goers and the grandiloquent language of programme music, contemplating simplicity.

The Awakening and "The String Quartet" present a rich range of possibilities for the classroom, be they textual, historical, or cultural. The topos of the concert is as much a means of characterization as a tool of satire on the society. It also brings to the foreground the question of signification, both in The Awakening and "The String Quartet." But most importantly, the musical context allows one to deal with the subject of representation and the question of signification on the whole.

The difficulty of describing music and the recourse to pictorial depiction of it may be used as one possible springboard for discussion of differences in representation between different arts. Programme music may be tackled in accordance with the notion of mimesis. It may be helpful to listen to musical excerpts and discuss them. One may use Camille Saint-Saëns's Carnival of the Animals, or even more ancient compositions, such as Ignaz Heinrich Biber's Sonata Representativa.

Consequently, the thematic or topical relationship between music and literature requires a specific contextualization. It seems obvious that the musical or extramusical context of the texts mentioning or speaking about music, however indirectly, needs to be accounted for. I have recently come across a poem by Galway Kinnell, "Farewell". The poem clearly draws on Joseph Haydn's Farewell Symphony (n45). According to the legend surrounding this work, Haydn composed the symphony to show his patron, Prince Nikolaus Esterházy, that the musicians he employed should be given a leave - in the final adagio (alluded to in Kinnell's poem) the musicians gradually leave the stage, so that there are only two violins left in the end. The symphony thus presents us with a progressive disintegration of music, which characterizes the farewell theme in the poem. 
I wish to suggest that such contextualizations lead us to raise questions about literariness itself. The representation of the concert not only provides us with important clues as to the historical dimension of reading and listening, but it is also quite telltale as to the questions of meaning and representation, generally speaking. Hence, not only is the musical context a necessary background for literary interpretation, but it also becomes a wellspring of questions one may raise about literature and literariness.

\section{2) Musical forms showing through literature}

\section{Zones of musicalization}

In Aldous Huxley's Point Counter Point, the musico-literary relationship is defined "not in the symbolist way [...] but on a large scale, in the construction," (Huxley, 293). It is called musicalization of fiction, referring to texts modelled on musical forms or techniques. But then structural parallels between literature and music face many a stumbling block, mainly because of the semiotic or temporal differences between the two arts. The use of musicalized texts in class may thus seem quite difficult, since considerable specialized knowledge of musical techniques is needed.

I wish to suggest that it is possible to deal with musicalized texts on a broader and more abstract level. It seems quite obvious that imitating musical forms in literary texts cannot be considered verbatim as the transfer of a formal entity from one medium into the other. Given the necessary transformations, the process is much looser than is often acknowledged. But it is also important to avoid ungrounded and generalizing statements. It thus seems necessary to strike a balance between overly literal readings of musicalized texts and overly loose interpretations of music in literature. Furthermore, music highlights some specifically literary aspects, and, once again, it may well be used as a springboard for discussing literary questions.

First, one possible notion that can prove interesting in the classroom is the idea of rhythm or, perhaps more generally, the question of speed. Rhythm may be paralleled with metrics and prosody on the whole, but it is not to be limited to verbal rhythm. I tend to consider the musicalization of fiction as a local phenomenon - rather than a formal literary design dependent on music through and through, it has more to do with areas or zones of musicalization. The idea of zones implies that there is a variation of intensity of musical formalism in literary texts, and the rhythmical aspects of narrative fiction are, in my opinion, predicated precisely on fluctuating intensities.

It can be useful to draw comparisons between poetic feet and rhythmical units in music. Some musicalized texts resort to metrical transposition. In Anthony Burgess's Mozart and the Wolf Gang, the initial rhythmic unit from Mozart's 40th Symphony is imitated by the text by the use of anapaests ("he himself he himself he himself trod" (Burgess, 81)). It may be interesting to make students listen to the composition before reading the text. No particular musical knowledge should be necessary and the recourse to poetic feet should be sufficient.

Yet prosody is on no account the equivalent of the musical rhythm, judging by the lack of bars or simply by the fact that musical rhythm is far more precise than the poetic rhythm could ever be. Moreover, in literature rhythm is also dependent on meaning, which music lacks. In fact, numerous texts denote or connote speed without their verbal rhythm being any swifter, additionally to prosodic devices. 
The flight sequence of The Giaour remains in iambic tetrameter all through, even though the sensation of an incredibly fast pace grows and grows. The speed is above all predicated on the lexical field of flight ("hastened", "flew", "flight", "speed"), riding ("hoofs", "spurs", "stirrup"), and disappearance ("passed and vanished", "the rock relieves him from my eye"). The impression of quickening is mostly semantic, which does not rule out the acoustic dimension as a means of rhythmical suggestibility.

In Conrad Aiken's novel, Great Circle, the speed is evoked both by dwelling on words pregnant with rhythmic connotation and the verbal imitation of speed through repetition or onomatopoeia:

Hurry - hurry - hurry everything was hurrying. The train was hurrying. The world was hurrying. The landscape was hurrying. The wheels rushed blindly over the rails, over the joints, over the switches: ratte-tat-te-tattle-te-tat-te-tump-te-tattle-te-tee. The locomotive driver, or the fireman [...], was obsessed with the panic of speed, and blew prolongedly and repeatedly on the whistle. Scarcely a minute was left unpunctuated by the moan of the whistle [...]. The whole world, it seemed, was to be made conscious of the important hurry of the train. (Aiken, 170)

Alongside prosodic devices, the text makes use of the semantic potential of words in order to suggest increasing speed, extendedly exploring the lexical field of celerity.

The idea of zones appears quite clearly in William H. Gass's “The Pedersen Kid". Divided into three parts, each of which is in its turn split into three, the novella presents us with a highly perceptible formalism, whose culminating point is operated through at least two zones of great intensity. Indeed, two final passages show both an accretion of contrapuntal intensity (as a superimposition of discourses) and an accretion of repetitive intensity. The latter is further magnified by the typographical device of voids:

The wagon had a great big wheel. Papa had a paper sack. Mama held my hand. High horse waved his tail. Papa had a paper sack. We both ran to hide. Mama held my hand. The wagon had a great big wheel. $\quad$ High horse waved his tail. We both ran to hide [...]. (Gass, 75-76)

If one considers the text as a contrapuntal composition - in an interview Gass mentions the round (canon) as its structural model - it becomes possible to interpret these two passages as fugal stretti, i.e. zones of heightened polyphonic overlapping of voices. Although, it seems difficult to work with students on the fugue in relation to this text, it may be interesting to compare the literary devices used to regulate gradation, intensity and culmination with the musical devices that govern direction and progression, such as the fugal stretti (one may listen to Bach fugues from the Well-Tempered Clavier).

\section{Intermediality, intertextuality and musical forms in literature}

Second, beside the notion of zones, it is also necessary to consider the texts modelled on musical forms within the context of a broader intermediality and that of literary intertextuality itself.

Josipovici's Goldberg: Variations comprises structural elements in reference to Bach's composition. The music and the novel are both predicated on the notion of circularity. Some of the elements contributing to the idea of the cycle may be pointed out without students' knowing how to read or analyze music. One may resort to presenting them with the symbolical construction of numbers in Bach's music. Both the Aria and the variations are built upon the fundamental bass in two parts. Each part comprises sixteen bars, played twice. The range of the musical phrase is founded on four bars each. All this amounts to an architecture based on the multiplicity of the number four going up to sixty-four. The Goldberg Variations may be divided into two parts, each comprising fifteen variations and the Aria which is repeated (da capo) at the end, which brings us back to the number thirty-two. 
Consequently, there are levels of embedding in terms of numerical organization. One may bring that to the student's notice with the aid of the score, without necessarily going into detail as to the harmonic unfolding of the composition. A parallel may thus be drawn between the musical text and the literary text on the level of construction. Students may be encouraged to look for elements of circularity within the novel. The first chapter of the novel already establishes a cycle: Goldberg is going to write a text about the impossibility of writing. A strange loop is achieved: the metatextual turn of the text is at one with the notion of the cycle.

It may also prove interesting to draw comparisons between other literary adaptations of the Goldberg Variations. Richard Powers's The Gold Bug Variations may be apprehended not only through Bach's composition, but also through E.A. Poe's short story, "The Gold Bug," on which the title is a pun. What Powers's novel enhances is the play with meaning and ciphers just as Poe or Bach toy with numbers, both as symbols and secrets to decipher. In this regard, it may be useful, even if one does not study The Gold Bug Variations in the classroom, to read through Powers's structural response to Bach's Aria from the Goldberg Variations: four poems ("The Perpetual Calendar"), each in four quatrains.

The question of drawing on some structural feature of music may thus be put across to students provided it is done on a rather abstract level. A comparative approach being already a synthetic activity per se, intermedial teaching materials only sharpen it. Often enough interartistic materials permit one to get back to literariness, since the techniques of intersemiotic translation can but operate through literary devices. Hofstadter's "Crab Canon" in Gödel, Escher, Bach: An Eternal Golden Braid renders the backward motion of Bach's canon from the Musical Offering by means of a palindrome. Students may read through Hofstadter's text listening to Bach's canon.

The need to examine literary devices themselves when analyzing intermedial texts appears clearly in Josipovici's Goldberg: Variations as well. Searching for variations in the novel, one may come across a stumbling block: the theme is rather hard to find [10]. But in spite of this, there undoubtedly appears what one may call transtylization [11], that is to say a diversity of styles, methods or devices. In this respect, the novel does bring forward a set of variations, in a broader sense. But then, the idea of variation makes one wonder not so much about the musical form, but about specifically literary questions of stylistic hybridization, multiple narration, perspectivism, or literary genres - among the different types of writing the novel comprises epistolary, dialogic or narrative techniques. Unavoidably, intermediality and the musicalization of fiction seem to lead to reconsidering textuality itself: there is certainly a degree of reflexivity and mirroring at stake.

Also, just as in the case of Hofstadter's text referring not only to Bach's music but also to M.C. Escher's etchings, Josipovici's novel resorts to pictorial devices. Goldberg: Variations makes use of the ekphrasis, the postcard, the curiosity cabinet or the trompe-l'oil. Intermediality involves thinking about the arts on the whole, and quite often requires a synthetic approach to several media in tandem. Josipovici's short story, "Absence and Echo," stages a dialogue between two characters who, contemplating a painting by Vermeer, wonder not only about the pictorial, but about the musical as well, for the arts are embedded.

Considering the musicalization of fiction within a broader intermedial context of forms allows one to draw rich structural comparisons. This approach is justified by the contemporary intermedial turn in the arts, observable in numerous interartistic festivals or events and in the 
rise of intersemiotic creation such as digital literature. It also makes us appreciate earlier contexts of interartistic cooperation, which may either be conceived of as intermedial complementarities (sister arts) or interartistic confrontation or rivalry (agonistics). In teaching musical fiction to more advanced students, it thus seems useful to refer to more general, intermedial handbooks first, such as William Fleming's Arts and Ideas or Thomas Munro's The Arts and Their Interrelations.

\section{Conclusion}

In the light of the extended musico-literary bibliographies and the importance of intermediality in the contemporary artistic activity, I think that the impact music exerts upon the literary should be reconsidered and that more musico-literary materials should be used in teaching literature, if not as an independent subject matter, at least as ancillary materials just as painting or film already are. If it appears quite clear that difficulties arise when technical musical skills are needed for formal analysis, in many literary works, however, music provides a general historical or cultural context that can be explained without necessarily calling for musicological competence. I also think that every time an art resorts to parallels with other arts, it becomes self-reflective, so that dealing with music in literature often makes us raise literary questions. I am convinced that the classroom will only benefit from opening up to this universal language and will gain from intermedial synergies.

\section{Endnotes}

[1] See Hollander, John. "Music and Poetry." Princeton Encyclopedia of Poetry and Poetics. Ed. Alex Preminger. Princeton: PUP, 1974. 533-536.

[2] See, for example, Brown, Kellie D. An Annotated Bibliography and Reference List of Musical Fiction. Lewiston: Edwin Mellen Press, 2005.

[3] Brown, Calvin S. Music and Literature: A Comparison of the Arts. Hanover: UP of New England, 1987.

[4] Scher, Steven P. "Literature and Music." Interrelations of Literature. Ed. Barricelli and Gibaldi. New York: The Modern Language Association of America, 1982. 225-250.

[5] Wolf, Werner. The Musicalization of Fiction: A Study in the Theory and History of Intermediality. Amsterdam, Atlanta: Rodopi, 1999.

[6] See G.K. Chesterton's essay "Music with Meals." Pleasures of Music: An Anthology of Writing about Music and Musicians from Cellini to Bernard Shaw. Ed. Barzun, Jacques. Chicago: The UP of Chicago, 1951.

[7] One may decide to listen to Johann Hermann Schein's Banchetto musicale (1617), Thomas Simpson's Taffel-Consort (1621), or Georg Philipp Telemann's Tafelmusik (1733).

[8] See Pascal Quignard's essay "Il se trouve que les oreilles n'ont pas de paupières ("It so happens that our ears have no eyelids"). La Haine de la musique. Paris : Calmann-Lévy, 1996. 105-136.

[9] See, for instance, Balzac, Honoré de. Illusions perdues. Paris: Gallimard, 1961.

[10] See Werner Wolf's discussion in "The Role of Music in Gabriel Josipovici's Goldberg: Variations." Style 37.3 (2003): 294-317.

[11] See Gérard Genette, Palimpsestes. La littérature au second degré. Paris: Seuil, 1982.

\section{Works cited}

Aiken, Conrad. Great Circle. In The Collected Novels of Conrad Aiken. 167-295. New York: Holt, Rinehart and Winston, 1964.

Balzac, Honoré. Illusions perdues. Paris, Gallimard, 1961.

Barzun, Jacques (Ed.). Pleasures of Music: An Anthology of Writing about Music and Musicians from Cellini to Bernard Shaw. Chicago: U of Chicago P, 1951. 
Brown, Calvin S. Music and Literature: A Comparison of the Arts. Hanover: UP of New England, 1987.

Brown, Kellie. An Annotated Bibliography and Reference List of Musical Fiction. Lewiston: Edwin Mellen Press, 2005.

Burgess, Anthony. Mozart and the Wolf Gang. London: Vintage, 1992.

Byron, George G. The Giaour. The New Oxford Book of Romantic Period Verse. Ed. Jérome J. McGann. Oxford: Oxford UP, 1994. 316-350.

Cather, Willa. The Song of the Lark. New York: Dover, 2004.

Chopin, Kate. The Awakening. New York: Avon Books, 1972.

Fleming, William. Arts and Ideas. Fort Worth: Holt, Rinehart and Winston, 1986.

Gass, William H. "The Pedersen Kid.” Boston: Nonpareil Books, 1981. 1-79.

Genette, Gérard. Palimpsestes. La littérature au second degré. Paris: Seuil, 1982.

Hofstadter, Douglas R. "Crab Canon." Gödel, Escher, Bach: An Eternal Golden Braid. New York: Basic Books, 1979. 198-203.

Huxley, Aldous. Point Counter Point. Illinois: Dalkey Archive Press, 2001.

Josipovici, Gabriel. "Absence and Echo." In the Fertile Land. Manchester: Carcanet, 1987. 35-39.

---. Goldberg: Variations. Manchester: Carcanet, 2002.

Kinnell, Galway. "Farewell." A New Selected Poems. Boston: First Mariner Books, 2001. 144-145.

Munro, Thomas. The Arts and Their Interrelations. Cleveland: P of Case Western Reserve U, 1969.

Poe, Edgar A. "The Gold-Bug." Selected Tales. London: Penguin, 1994. 273-310.

Powers, Richard. The Gold Bug Variations. New York: Harper Perennial, 1991.

Villiers, de l'Isle-Adam. "Unknown Woman." Cruel Tales. New York: Oxford UP, 1963. 201-214.

Proust, Marcel. A la recherche du temps perdu. Paris, Gallimard, 1954.

Quignard, Pascal. La Haine de la musique. Paris: Calmann-Lévy, 1996.

Radcliffe, Ann. The Mysteries of Udolpho. London: Penguin, 2001.

Scher, Steven P. "Literature and Music." Interrelations of Literature. Ed. Barricelli and Gibaldi. New York: The Modern Language Association of America, 1982. 225-250.

Tremain, Rose. Music and Silence. London: Vintage, 2000.

Wolf, Werner. The Musicalization of Fiction: A Study in the Theory and History of Intermediality. Amsterdam, Atlanta: Rodopi, 1999.

---."The Role of Music in Gabriel Josipovici's Goldberg: Variations." Style 37.3 (2003): 294317.

Woolf, Virginia. "The String Quartet." A Haunted House and Other Stories.

Orlando: Harcourt, 1972. 22-27. 